\title{
Growth and yield of cactus pear under irrigation frequencies and nitrogen fertilization
}

\author{
José Dantas Neto ${ }^{1}$, Rigoberto M. de Matos ${ }^{1}$, Patrícia F. da Silva ${ }^{2}$, Antonio S. de Lima ${ }^{1}$, \\ Carlos A. V. de Azevedo ${ }^{1} \&$ Luciano M. F. Saboya ${ }^{1}$
}

\begin{abstract}
${ }^{1}$ Universidade Federal de Campina Grande/Centro de Tecnologia e Recursos Naturais/Unidade Acadêmica de Engenharia Agrícola. Campina Grande, PB, Brasil. E-mail: zedantas1955@gmail.com - ORCID: 0000-0003-0798-6717; rigobertomoreira@gmail.com - ORCID: 0000-0003-3455-9876; suassunaagro@gmail.com - ORCID: 0000-0002-4411-3985; cvieiradeazevedo@gmail.com - ORCID: 0000-0001-7336-1243; lsaboya@hotmail.com ORCID: 0000-0002-7586-6867

${ }^{2}$ Universidade Federal de Campina Grande/Centro de Tecnologia e Recursos Naturais/Programa de Pós-Graduação em Engenharia e Gestão dos Recursos Naturais. Campina Grande, PB, Brasil. E-mail: patrycyafs@yahoo.com.br (Corresponding author) - ORCID: 0000-0002-4580-2336
\end{abstract}

\begin{abstract}
Microirrigation associated with nitrogen $(\mathrm{N})$ fertilization aims to meet the water and nutritional demands of cactus pear. The objective of this study was to evaluate the growth and yield of cactus pear (Opuntia ficus-indica) irrigated by microirrigation and fertilized with $\mathrm{N}$. The experiment was conducted in the field at the Poço Redondo farm, Santa Luzia, PB, Brazil (6 $6^{\circ} 52^{\prime} 27^{\prime \prime}$ S and 36 56' $0^{\prime \prime}$ W and altitude of 299 m), between April and December 2017. The experimental design was in randomized blocks in a $5 \times 2$ factorial scheme, with five irrigation frequencies $(7,14,21,28$ and 35 days) and two types of fertilization (soil fertilized with $\mathrm{N}$ and not fertilized) in the cultivar 'Orelha de Elefante Mexicana', with three replicates. Different irrigation frequencies promote reduction in green biomass yield and increase in the economic water productivity when using of the cladode for propagative material. Nitrogen fertilization increased growth, green biomass yield, water productivity and economic water productivity. The greatest economic return is obtained by producing cladodes marketed for propagative material. Reducing the frequency of irrigation promotes greater water saving, increasing the irrigated area and production by using less water at high frequency.
\end{abstract}

Key words: Opuntia sp., urea, deficit irrigation, yield, economic return

\section{Crescimento e produtividade de palma forrageira sob frequências de irrigação e adubação nitrogenada}

\begin{abstract}
RESUMO: A microirrigação associada à fertilização nitrogenada visa suprir a demanda hídrica e nutricional da palma forrageira. Objetivou-se, com este estudo, avaliar o crescimento e a produtividade da palma forrageira irrigada por microirrigação e fertilizada com nitrogênio. O experimento foi conduzido a campo, na fazenda Poço Redondo, Santa Luzia, PB, Brasil (6 52' 27" S e 36 56’ 0” W e altitude de $299 \mathrm{~m}$ ), entre abril e dezembro de 2017. O delineamento experimental foi em blocos casualizados no esquema fatorial $5 \times 2$, sendo cinco frequências de irrigação $(7,14,21,28$ e 35 dias) e dois tipos de fertilização (solo fertilizado com nitrogênio e não fertilizado), na cultivar Orelha de Elefante Mexicana, com três repetições. Diferentes frequências de irrigação promovem decréscimo na produtividade de biomassa verde e acréscimo na produtividade econômica da água quando se utiliza o cladódio para semente na palma forrageira cv. Orelha de Elefante Mexicana. A fertilização nitrogenada aumentou o crescimento e as produtividades de biomassa verde, da água e econômica. O maior retorno econômico é obtido com a produção de cladódios comercializados para material propagativo. A redução da frequência de irrigação proporciona maior economia de água, aumentando a área irrigada e a produção, ao utilizar menor volume de água com alta frequência.
\end{abstract}

Palavras-chave: Opuntia sp., ureia, irrigação deficitária, rendimento, retorno econômico 


\section{INTRODUCTION}

The search for more efficient irrigation has become a routine for researchers and irrigators. Among the methods that most add technology, microirrigation stands out with micro-sprinkler and drip irrigation systems, in which water is conducted through pipes up to the point of application by emitters installed along a pipe parallel to the plant row. For Frizzone et al. (2012), microirrigation is characterized by applying water at low flow rate, for a relatively long time and with high frequency.

The growth and yield of cactus pear vary with rainfall levels and soil fertility. Cunha et al. (2012) state that the soils of the northeastern semi-arid region have low levels of organic matter and low nitrogen $(\mathrm{N})$ availability for plants. Therefore, using external $\mathrm{N}$ sources is essential to increase the biomass production of cactus pear.

Pereira et al. (2015) report that in most of the Brazilian semi-arid region, rainfall is concentrated in four months of the year. Thus, in order to reach the maximum production potential, cactus pear needs adequate techniques of irrigation and fertilization management, indicated as influential factors to obtain high yields (Guan et al. 2015; Rocha et al., 2017).

Some authors report that cactus pear yield tends to increase under irrigation and mineral fertilization. However, it is necessary to quantify the adequate volume of water to be applied, as well as the best irrigation frequency and dose of nutrient applied (Queiroz et al., 2015; Pereira et al., 2015; Lima et al.; 2016; Silva et al., 2016a, b; Cunha et al., 2012).

Given the relevance of the theme, the objective of this study was to evaluate the growth and green biomass yield, water productivity and economic water productivity of cactus pear irrigated by microirrigation with low frequency and fertilized with $\mathrm{N}$.

\section{Material And Methods}

The experiment was conducted under field conditions at Poço Redondo farm, municipality of Santa Luzia, PB, Brazil, from April to December 2017. The experimental area is located in the Seridó Ocidental Paraibano microregion, with geographical coordinates: 6 $6^{\circ} 52^{\prime} 27^{\prime \prime}$ S Latitude, 36 56’ 0” W Longitude and average altitude of $299 \mathrm{~m}$. The local climate is Bsh, tropical, hot and dry, semi-arid with summer rains.

The soil of the experimental area is classified as Fluvent, with sandy loam texture. This type of soil exhibits a great variation in its characteristics, for being composed of materials from alluvial debris, and its physical and chemical characteristics in the 0-0.2 m layer, determined according to the methodology of EMBRAPA (2014), are shown in Table 1.
The experimental design adopted was in randomized blocks in a $5 \times 2$ factorial scheme, with the first factor corresponding to five irrigation frequencies $(7,14,21,28$ and 35 days) and the second factor to $\mathrm{N}$ fertilization (soil fertilized and not fertilized with $\mathrm{N}$ ), with three replicates, totaling 30 experimental plots.

The experiment was conducted using the cactus pear cultivar 'Orelha de Elefante Mexicana' (Opuntia ficus-indica L. Mill), which is resistant to cochineal (Dactylopius opuntiae), besides being one of the most cultivated by producers in the region.

The experimental plots consisted of a double row of plants with spacing of $0.4 \mathrm{~m}$ between rows, $2.0 \mathrm{~m}$ between double rows and $0.5 \mathrm{~m}$ between plants, with $3.0 \mathrm{~m}$ in length and $1.0 \mathrm{~m}$ of border. Only the four central plants located in the area of the plot were considered for analyses.

Basal fertilization was performed using $200 \mathrm{~kg} \mathrm{ha}^{-1}$ of monoammonium phosphate (MAP) as a source of phosphorous and $108.3 \mathrm{~kg} \mathrm{ha}^{-1}$ of potassium chloride as a source of potassium, following the recommendations of Santos et al. (2006) and based on the results of soil analysis. Along with basal fertilization, approximately $1.0 \mathrm{~kg}$ of bovine manure per linear meter was also applied in all experimental plots. Nitrogen fertilization was applied via fertigation, split into six portions, applied every thirty days, using $600 \mathrm{~kg} \mathrm{ha}^{-1}$ of urea as source of $\mathrm{N}$.

Cladodes were planted in furrows with bilateral alignment (domino type), in which the material was subjected to a 7-day healing period in the shade, aiming at the loss of part of the moisture. This interval also serves to heal the injuries caused in the cladode by the cutting operation in the field.

The irrigation method used was microirrigation, with a drip system, consisting of 25-m-long collapsible tubes with internal diameter of $16 \mathrm{~mm}$, wall thickness of $0.2 \mathrm{~mm}$, spacing between emitters of $0.20 \mathrm{~m}$, nominal pressure of $7.0 \mathrm{~m}$.w.c. and flow rate of $6.0 \mathrm{~L} \mathrm{~h}^{-1} \mathrm{~m}^{-1}$. The efficiency of water application (Ea) by the irrigation system was determined in the field and was equal to 0.96 .

The water used for irrigation was pressurized from a shallow well located $80 \mathrm{~m}$ away from the research area, by means of a 3.0-hp centrifugal motor pump. To prevent the entry of suspended particles larger than the diameter of the emitters into the system, a 2.0-inch disc filter was used.

The irrigation depth applied in each treatment was determined by Eq. 1, considering the five irrigation frequencies $(7,14,21,28$ and 35 days).

$$
\mathrm{GID}=\frac{(\theta \mathrm{FC}-\theta \mathrm{actual}) \cdot \mathrm{Z} \cdot \mathrm{Pwa}}{\mathrm{Ea}}
$$

Table 1. Physical and chemical characteristics of the soil used in the experiment

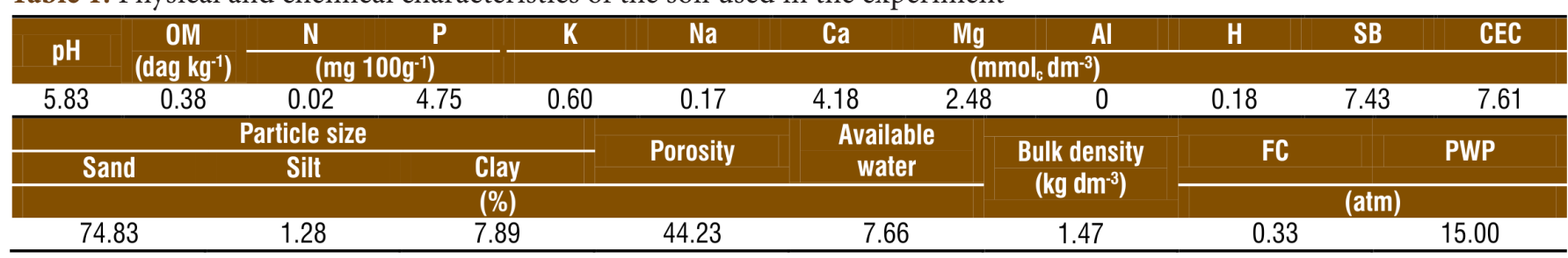

pH - Hydrogen potential; OM - Organic matter, N - Nitrogen, P - Phosphorus; K - Potassium; Na - Sodium; Ca - Calcium; Mg - Magnesium; Al - Aluminum; H - Hydrogen; SB - Sum of bases; CEC - Cation exchange capacity; FC - Field capacity, PWP - wilting point permanently 
where:

GID - gross irrigation depth applied, in $\mathrm{mm}$;

$\theta F C$ - soil moisture at field capacity, in $\mathrm{cm}^{3} \mathrm{~cm}^{-3}$;

$\theta$ actual - actual soil moisture before irrigation, in $\mathrm{cm}^{3} \mathrm{~cm}^{-3}$;

$\mathrm{Z} \quad$ - effective depth of the crop root system $(200 \mathrm{~mm})$;

Pam - percentage of wetted area determined in the field (0.33), according to Frizzone et al. (2012); and,

$\mathrm{Ea}$ - water application efficiency of the drip irrigation system (0.96).

Access tubes were installed for each frequency at depths of 0.1, 0.2 and $0.3 \mathrm{~m}$, and a TDR - Time Domain Reflectometry device, model PR2/6, was used to determine soil moisture twice a week before irrigation. Thus, it was possible to know the soil moisture content, hence enabling the evaluation of crop water consumption as a function of the irrigation frequencies.

Probe calibration under field conditions followed the methodology proposed by Lima et al. (2017), according to Eq. 2.

$$
\mathrm{UO}=0.2341 \mathrm{UP}+0.0355
$$

where:

UO - moisture determined by the oven method, in $\mathrm{m}^{3} \mathrm{~m}^{-3}$; and,

UP - moisture measured with the probe, in $\mathrm{m}^{3} \mathrm{~m}^{-3}$.

Until 60 days after planting (DAP) the mother cladodes, all treatments received the same irrigation depth at 7 -day intervals. From 60 to 240 DAP, the irrigation depths were applied according to the treatments. The volume applied was determined by the probe calibration equation and computed with flow meters in each treatment.

Plant height was measured with a measuring tape, considering the vertical distance from the soil to the highest end of the plant, while width was measured considering the greatest horizontal distance. The total number of cladodes was obtained by direct count.

The actual yield of cactus pear was determined in the field at six months after the beginning of treatments. Plants were cut at the first insertion, leaving only the mother cladode, and then all cladodes harvested were weighed on a precision scale.

Water productivity was calculated by relating the green biomass yield of the cactus pear to the water volume applied in each experimental plot, which makes it possible to evaluate the capacity of the crop to convert the volume of water into green biomass, according to Eq. 3 (Frizzone et al., 2012).

$$
\mathrm{WP}=\frac{\mathrm{Y}}{\mathrm{VW}}
$$

where:

WP - water productivity, in $\mathrm{kg} \mathrm{m}^{-3}$;

$\mathrm{Y}$ - green biomass yield of cactus pear, in $\mathrm{kg} \mathrm{ha}^{-1}$; and,

$\mathrm{Vw}$ - total volume of water applied along the crop cycle, in $\mathrm{m}^{3} \mathrm{ha}^{-1}$.

Economic water productivity was obtained by relating the gross revenue from the sale of cladodes to the water consumption, making it possible to evaluate the gross economic return as a function of each unit of water used in production, Eq. 4 (Araya et al., 2011).

$$
\mathrm{EWP}=\frac{\mathrm{GR}}{\mathrm{VW}}
$$

where:

EWP - economic water productivity, in $\mathrm{R} \$ \mathrm{~m}^{-3} \mathrm{ha}^{-1}$;

GR - gross revenue from the sale of cactus pear cladodes, in $\mathrm{R} \$ \mathrm{ha}^{-1}$; and,

$\mathrm{Vw}$ - total volume of water applied along the crop cycle, in $\mathrm{m}^{3} \mathrm{ha}^{-1}$.

Economic gain was obtained considering the sale value of R\$ 300.00 (90.36 USD) per ton of cactus pear green biomass destined for animal feed, and R $\$ 0.25$ (0.07 USD) per unit of cactus pear cladode destined for sale as propagative material (seed).

These values are those practiced in the commercialization of cactus pear by the producers in the semi-arid region where the study was conducted. The U.S. dollar was quoted at R $\$ 3.32$ on December 30, 2017.

After quantifying the water volume for each irrigation frequency, the area to be planted was estimated by relating the water volume applied in the period for the cultivar 'Orelha de Elefante Mexicana' to the occupied area, extrapolating it to 1 ha.

The data were subjected to analysis of variance $(\mathrm{p} \leq 0.05)$. Subsequently, data referring to irrigation frequency were subjected to polynomial regressions and those referring to $\mathrm{N}$ fertilization to Tukey test, using the statistical program Sisvar 5.6 (Ferreira, 2014).

\section{Results AND Discussion}

Irrigation frequency significantly influenced the green biomass yield (GBY) and the economic water productivity of the cladode for seed $\left(\mathrm{EWP}_{\text {seed }}\right)$ (Table 2$)$. For being a cactus plant, cactus pear has good adaptation to arid and semi-arid regions, with tolerance to long periods of drought and high water use efficiency (Pinheiro et al., 2014; Silva et al., 2015).

Significant effect of the fertilization factor were observed on all variables analyzed at $\mathrm{p} \leq 0.01$ by the $\mathrm{F}$ test, demonstrating that soil fertilization with $\mathrm{N}$ positively influenced cactus pear (Table 2). These results show that the variables studied were more responsive when subjected to fertilization through the application of $\mathrm{N}$ fertigation.

The interaction between the sources of variation did not influence any of the variables studied (Table 2).

Studying cactus pear under $\mathrm{N}$ doses, Cunha et al. (2012) report that it is indispensable to apply external $\mathrm{N}$ sources to increase cactus pear production, since $\mathrm{N}$ is a nutrient that stimulates cell division and promotes plant development.

The treatment with $\mathrm{N}$ fertilization promoted the highest means for plant height $(63.5 \mathrm{~cm})$, plant width $(86.6 \mathrm{~cm})$ and number of cladodes (13.9), differing from non-fertilized plants, which produced the lowest means: $44.8,56.3$ and $7.70 \mathrm{~cm}$, respectively (Figures $1 \mathrm{~A}$ and $\mathrm{B}$ ). 
Table 2. Summary of the analysis of variance for cactus pear cv. 'Orelha de Elefante Mexicana' as a function of irrigation frequency and nitrogen fertilization

\begin{tabular}{|c|c|c|c|c|c|c|c|c|}
\hline \multirow{3}{*}{ Sources of variation } & \multirow{3}{*}{ DF } & \multicolumn{7}{|c|}{ Mean squares } \\
\hline & & \multirow{2}{*}{ PH } & \multirow{2}{*}{ PW } & \multirow{2}{*}{ NC } & \multirow{2}{*}{ GBY } & \multirow{2}{*}{ WP } & \multicolumn{2}{|c|}{ EWP } \\
\hline & & & & & & & $\begin{array}{l}\text { Animal } \\
\end{array}$ & Seed \\
\hline Irrigation frequency (IF) & 4 & $25.82^{\text {ns }}$ & $31.12^{\mathrm{ns}}$ & $0.38^{\text {ns }}$ & $374.98^{\star *}$ & $32.67^{\mathrm{ns}}$ & $2.93^{\text {ns }}$ & $45.20^{\star \star}$ \\
\hline Linear equation & & $0.62^{\mathrm{ns}}$ & $76.84^{\text {ns }}$ & $0.02^{\mathrm{ns}}$ & $982.53^{\star \star}$ & $7.02^{\mathrm{ns}}$ & $0.63^{\text {ns }}$ & $165.23^{\star \star}$ \\
\hline Quadratic equation & & $14.00^{\text {ns }}$ & $1.52^{\mathrm{ns}}$ & $0.80^{\text {ns }}$ & $36.80^{\text {ns }}$ & $1.50^{\text {ns }}$ & $0.13^{\mathrm{ns}}$ & $13.16^{\text {ns }}$ \\
\hline Fertilization (FE) & 1 & $2609.60^{* *}$ & $6888.70^{\star \star}$ & $288.92^{* *}$ & $11321.86^{* \star}$ & $1771.47^{\star *}$ & $159.34^{* *}$ & $748.60^{* *}$ \\
\hline Interaction (IF) x (FE) & 4 & $7.67^{\mathrm{ns}}$ & $5.53^{\text {ns }}$ & $0.70^{n s}$ & $138.05^{\text {ns }}$ & $14.88^{\text {ns }}$ & $1.33^{\text {ns }}$ & $2.93^{\text {ns }}$ \\
\hline Block & 2 & 52.75 & 18.04 & 2.21 & 85.49 & 13.53 & 1.21 & 6.94 \\
\hline Residual & 18 & 13.20 & 46.34 & 2.33 & 69.61 & 11.80 & 1.06 & 6.39 \\
\hline CV (\%) & - & 6.71 & 9.53 & 14.14 & 16.59 & 17.18 & 17.19 & 14.43 \\
\hline \multirow{2}{*}{ Overall mean } & - & \multicolumn{2}{|c|}{$(\mathrm{cm})$} & & $\left(\right.$ t ha $\left.^{-1}\right)$ & $\left(\mathrm{kg} \mathrm{m}^{-3}\right)$ & \multicolumn{2}{|c|}{$\left(\mathrm{R} \$ \mathrm{~m}^{-3}\right)$} \\
\hline & & 54.16 & 71.42 & 10.80 & 50.29 & 19.99 & 5.99 & 17.52 \\
\hline
\end{tabular}

${ }_{\text {ns }}$ - Not significant; ${ }^{* *}$ - Significant at $\mathrm{p} \leq 0.01$ by F test; PH - Plant height; PW - Plant width; NC - Number of cladodes, GBY - Green biomass yield; WP - Water productivity; EWPanimal - Economic water productivity of the cladode for animal feed; EWPseed - Economic water productivity of the cladode for seed

A. $\square$ Plant height $\quad$ PPlant width

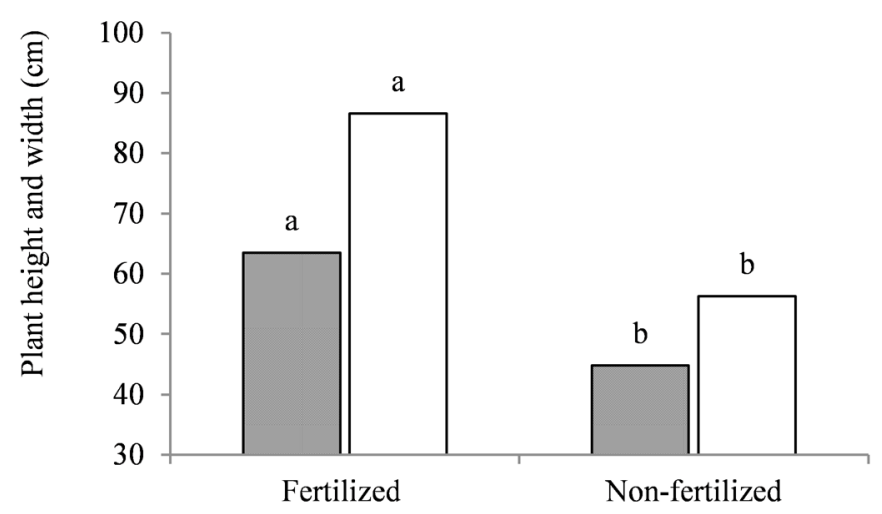

Fertilization

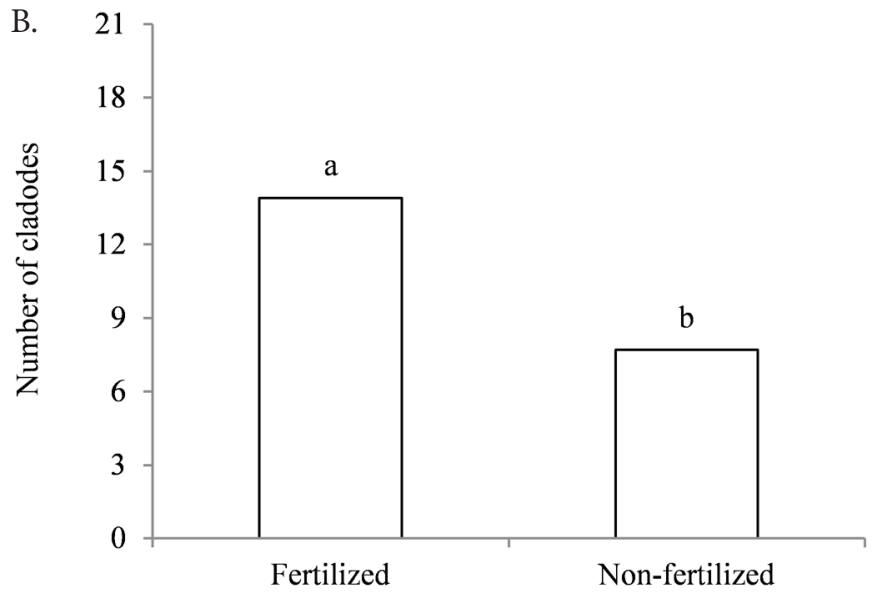

Fertilization

Means followed by the same letter, between bars with the same color, do not differ by Tukey test at $\mathrm{p} \leq 0.05$

Figure 1. Plant height and width (A) and number of cladodes (B) in cactus pear cv. Orelha de Elefante Mexicana as a function of nitrogen fertilization

The results of this study corroborate those reported by Silva et al. (2016b), who obtained greater height and width of cactus pear plants in the treatment subjected to mineral fertilization, which is possibly associated with greater availability of nutrients for the crop, specifically $\mathrm{N}$, when compared to the treatment without fertilization.
Silva et al. (2012) report that $\mathrm{N}$ is the nutrient with the greatest influence on the growth of cactus pear plants, as it promotes changes in plant morphology and, under high supply conditions, there is higher growth (Donato et al., 2014; Barros et al., 2016). This fact may justify the greater height and width of cactus pear plants subjected to fertilization.

Studying the morphology of cactus pear under mineral fertilization, Silva et al. (2016b) found that fertilization with NPK promoted a positive effect on the number of cladodes, increasing it from 9 in the absence of fertilizer to 15 cladodes in fertilized plants, which can be explained by the fact that $\mathrm{N}$ is the nutrient that stimulates cell division and promotes the appearance of new cladodes (Cunha et al., 2012; Silva et al., 2010).

The green biomass yield of cactus pear was significantly influenced by the individual factors irrigation frequency and $\mathrm{N}$ fertilization (Figures $2 \mathrm{~A}$ and $\mathrm{B}$ ).

It was verified that the green biomass yield of cactus pear decreased linearly with the reduction in irrigation frequency in days. The highest yield was estimated for the irrigation frequency of 7 days, corresponding to $60.2 \mathrm{t} \mathrm{ha}^{-1}$, while the lowest value $\left(40.4 \mathrm{t} \mathrm{ha}^{-1}\right)$ was obtained with the irrigation frequency of 35 days (Figure 2A).

A percentage reduction of $32.8 \%$ was found between the irrigation frequencies of 7 and 35 days. According to the regression equation, for each reduction of one day in the irrigation frequency the yield decreases by $0.706 \mathrm{tha}^{-1}$ (Figure $2 \mathrm{~A})$. Conversely, when the interaction of irrigation frequency within each $\mathrm{N}$ fertilization is analyzed, there is no significant difference, but the relative average of green biomass yield is higher in fertilized plants than in non-fertilized plants (Figure 2A). There is also a decreasing trend for both fertilizations and, with each one-day increment in irrigation frequency, the yield decreases by 1.05 and $0.42 \mathrm{tha}^{-1}$, respectively for fertilized and non-fertilized plants.

Pereira et al. (2015) studying the effect of three irrigation frequencies (7, 14 and 28 days) for the same cactus pear cultivar, found that irrigation frequencies had little influence on its agronomic characteristics. Such difference between the studies is justified by the climatic anomaly, since the accumulated rainfall in the twelve months of cultivation was $211 \mathrm{~mm}$, representing only $33 \%$ of the historical average $(642 \mathrm{~mm})$, occurred in the study of these authors. 

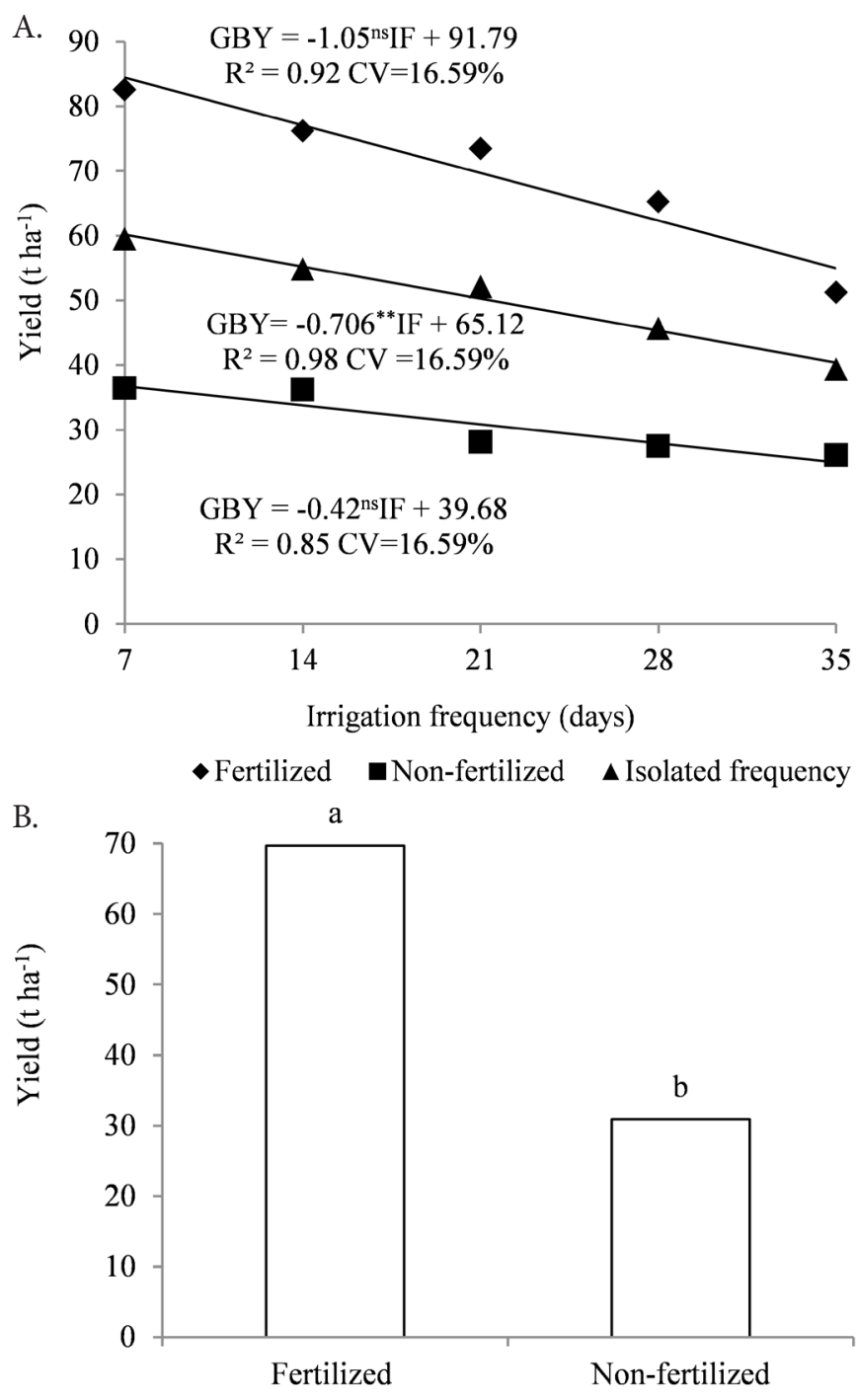

Fertilization

** - Significant by F test at $\mathrm{p} \leq 0.01$; Means followed by the same letter do not differ by Tukey test at $\mathrm{p} \leq 0.05$

Figure 2. Green biomass yield (GBY) of cactus pear cv. Orelha de Elefante Mexicana as a function of irrigation frequency (A) and nitrogen fertilization (B)

Results also diverging from those found in the present study were obtained by Queiroz et al. (2015), who evaluated the application of different irrigation depths on cactus pear yield and found that they did not cause significant changes in morphophysiological characteristics and yield.

The results presented in Figure 2A make it evident that, for being a plant with Crassulacean acid metabolism (CAM), cactus pear can produce green biomass even under water deficit, although it decreases with the increase in water limitation. According to Taiz \& Zeiger (2013), CAM plants when opening stomata at night reduce water loss to the environment, while allowing the entry of $\mathrm{CO}_{2}$, which is temporarily stored in malic acid and later used in photosynthetic reactions the following day.

The highest mean of green biomass yield of cactus pear at eight months after planting was obtained in plants fertilized with $\mathrm{N}\left(69.7 \mathrm{tha}^{-1}\right)$, while plants grown in unfertilized soil had yield of only $30.9 \mathrm{tha}^{-1}$, with a difference of $38.8 \mathrm{tha}^{-1}$ of green biomass (Figure 2B).
Cactus pear has high potential for green biomass yield. However, in order to express this production potential, it requires adequate and efficient management of soil fertilization (Nascimento et al., 2011; Cunha et al., 2012).

Increase in cactus pear yield with $\mathrm{N}$ fertilization was also observed by Cunha et al. (2012), who obtained green biomass yield of $197.0 \mathrm{tha}^{-1}$ using $300 \mathrm{~kg} \mathrm{ha}^{-1}$ of $\mathrm{N}$, while in the absence of $\mathrm{N}$ the green biomass yield was $175.4 \mathrm{tha}^{-1}$, in plants harvested at 18 months.

The lower green biomass yield obtained in the present study when compared to the study conducted by Cunha et al. (2012) can be justified by the fact that harvest was performed only eight months after the mother cladodes were planted in the field.

The variables water productivity and economic productivity of the water used in the cultivation of cactus pear differed statistically between fertilized and non-fertilized plants (Figures $3 \mathrm{~A}$ and $\mathrm{B}$ ).

The highest water yield $\left(27.7 \mathrm{~kg} \mathrm{~m}^{-3}\right)$ obtained with $\mathrm{N}$ fertilization was 2.25 times higher than that in non-fertilized
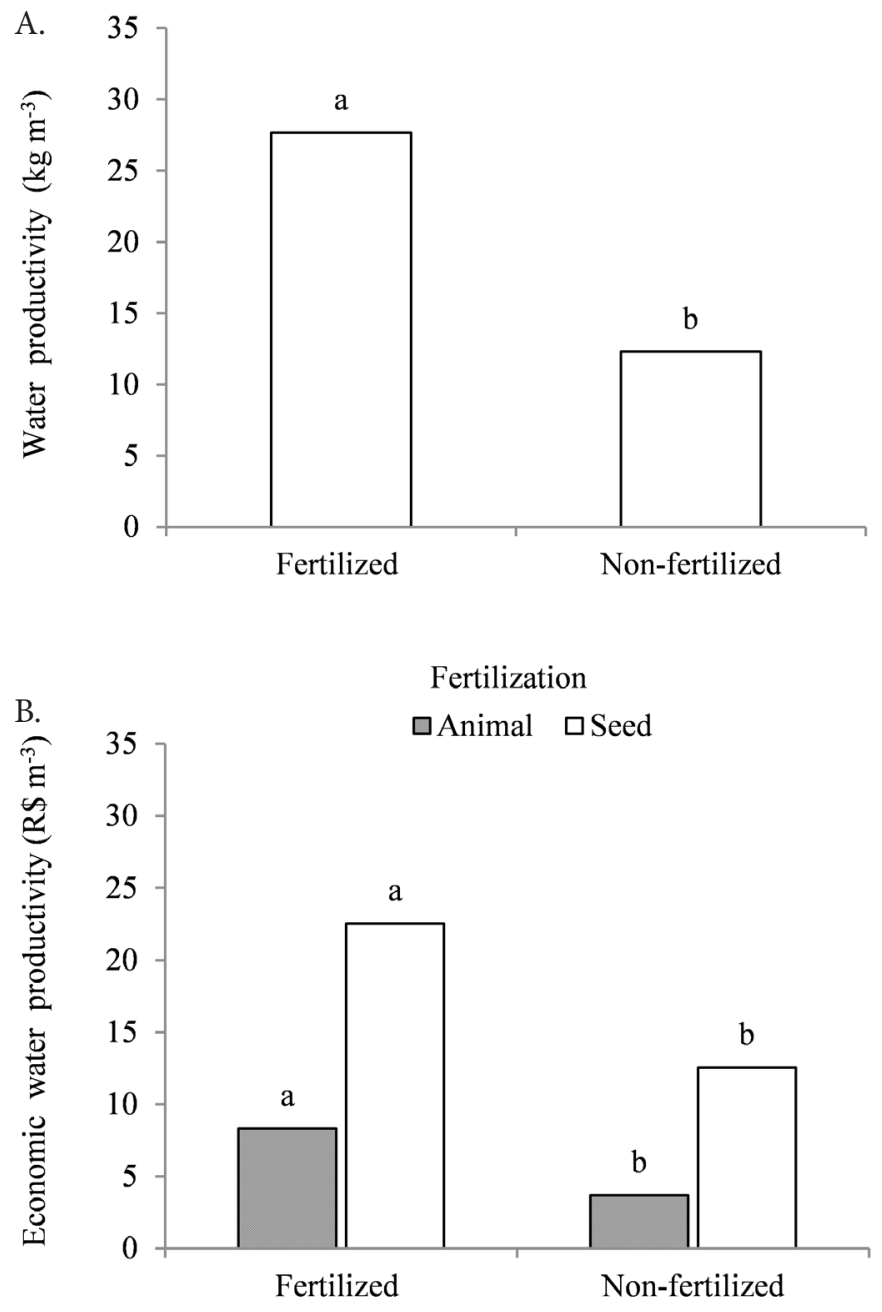

\section{Fertilization}

Means followed by the same letter, between bars with the same color, do not differ by Tukey test at $\mathrm{p} \leq 0.05$

Figure 3. Water productivity (A) and economic water productivity of cladodes for animal consumption (animal) and propagative material (seed) (B) of cactus pear cv. Orelha de Elefante Mexicana as a function of nitrogen fertilization 
plants $\left(12.3 \mathrm{~kg} \mathrm{~m}^{-3}\right)$ (Figure 3A). These values were higher than those observed by Silva et al. (2014), who studied cactus pear fertilized with $130 \mathrm{~kg}$ of $\mathrm{N} \mathrm{ha}^{-1}$ throughout the production cycle and under rainfed regime and found water productivity of $10.3 \mathrm{~kg} \mathrm{~m}^{-3}$.

Lima et al. (2016) report that, in cactus pear cultivation, the amount of water applied through irrigation is minimal, which provides the crop with high efficiency in its use, corresponding to water productivity. According to Taiz \& Zeiger (2013), the low water consumption of cactus pear occurs because it is a CAM species, in which about 50 molecules of water are lost for each $\mathrm{CO}_{2}$ molecule fixed by photosynthesis, resulting in a transpiration ratio of 50 . The inverse of the transpiration ratio is called water use efficiency. Plants with a transpiration ratio of 50 have water use efficiency of $1 / 50$ or 0.02 .

For the same amount of water applied, the higher the yield of the marketed product, the higher the economic water productivity. According to Figure $3 \mathrm{~B}$, the highest value obtained was $\mathrm{R} \$ 22.52 \mathrm{~m}^{-3}\left(6.78 \mathrm{USD} \mathrm{m}^{-3}\right)$ in plants under $\mathrm{N}$ fertilization, whose cladodes were sold as seed for planting.

This economic water productivity was higher than the values of $\mathrm{R} \$ 4.21 \mathrm{~m}^{-3}$ and $\mathrm{R} \$ 10.57 \mathrm{~m}^{-3}$ found by Silva et al. (2014) and Cruz Neto et al. (2017), in the cultivars 'Orelha de Elefante Mexicana' and 'Miúda', respectively. In both studies, the authors considered cladode price of $\mathrm{R} \$ 0.15$.

The lowest value of economic water productivity $\left(\mathrm{R} \$ 3.69 \mathrm{~m}^{-3}\right.$; USD $1.11 \mathrm{~m}^{-3}$ ) was obtained in plants not fertilized and sold as weight of green biomass intended for animal feed (Figure $3 \mathrm{~B})$. This value is $\mathrm{R} \$ 64 \mathrm{~m}^{-3}$ higher than that found by Cruz Neto et al. (2017), studying the cultivar 'Miúda', sold for $\mathrm{R} \$ 100.00$ per ton of green biomass.

Thus, according to the results presented in Figure 3B, using the same amount of water the cactus pear producer obtains higher economic return when selling cladodes for the production of "seeds" than when commercializing his production for animal feed.

The economic water productivity of the cladode for seed $\left(\mathrm{EWP}_{\text {seed }}\right)$ of 'Orelha de Elefante Mexicana' cactus pear increases as the irrigation frequency decreases, until it reaches a maximum value of $\mathrm{R} \$ 20.94 \mathrm{~m}^{-3}$, when it is irrigated every 35 days (Figure $4 \mathrm{~A}$ ). The difference in $\mathrm{EWP}_{\text {seed }}$, when comparing the irrigation frequency of 35 days to that of 7 days was $20.26 \%$. It is also noted that the one-day increment in irrigation frequency increased the economic water productivity by $\mathrm{R} \$ 0.24 \mathrm{~m}^{-3}$ (Figure 4A).

For the same amount of water applied, different values are obtained in the economic water productivity of the cladode destined for use as seed and, when the irrigation frequency in days was reduced, the economic profitability of water increased, a result that corroborates those obtained by Cruz Neto et al. (2017) when studying the economic water productivity of the cultivar 'Miúda'; however, these authors obtained values much lower than those of the present study. The difference in values between the two studies may be associated with different cultivars, and especially the fact that the present study used $\mathrm{N}$ fertilization, which favors the production of cladodes.

Cactus pear, for being a CAM plant, can be cultivated and irrigated in semi-arid regions with low water volume. Along the eight months of cultivation, the water volumes applied

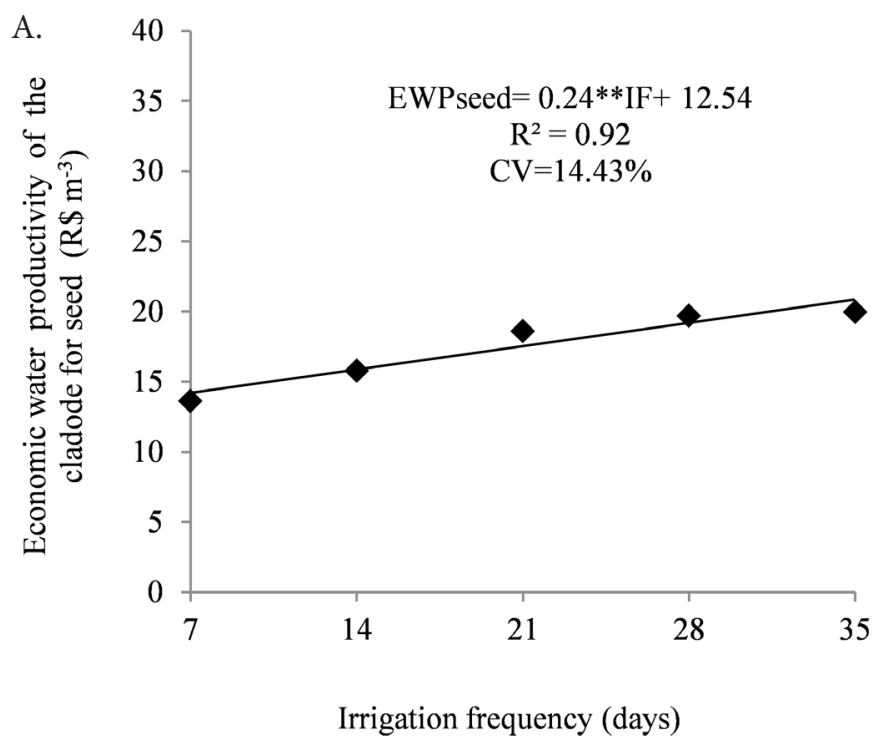

B. $\square$ Water volume $\quad$ - Planted area

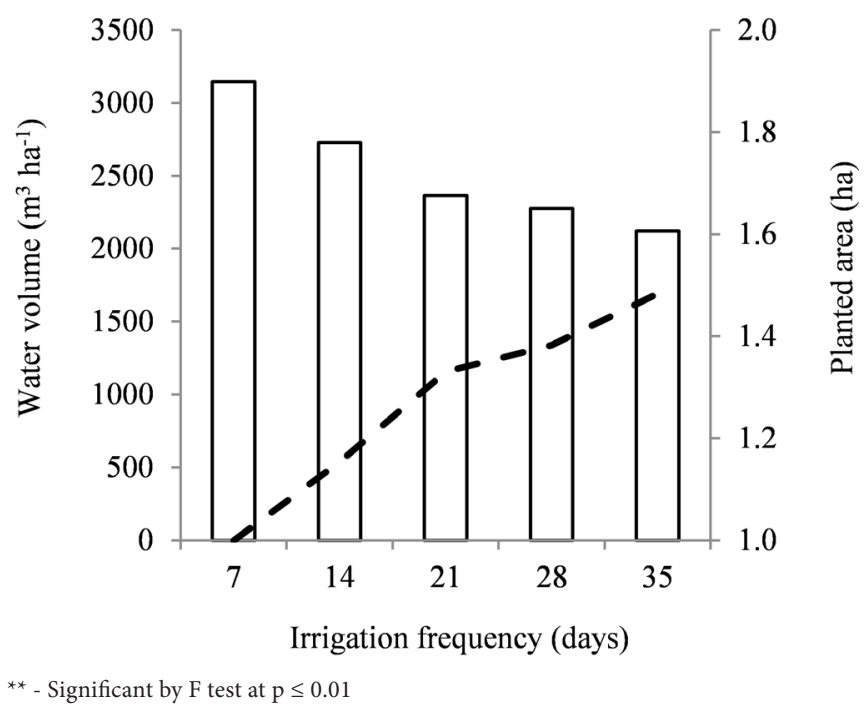

Figure 4. Economic water productivity of the cladode for propagative material (seed) (A), applied water volume and potential of irrigated area (B) in the cultivation of cactus pear cv. Orelha de Elefante Mexicana as a function of irrigation frequency

were $314.8,272.8,236.6,227.7$ and $212.2 \mathrm{~mm}$, respectively at irrigation frequencies of 7, 14, 21, 28 and 35 days, which are respectively equivalent to $3148,2728,2366,2277$ and $2122 \mathrm{~m}^{3} \mathrm{ha}^{-1}$ when transformed into volume per area.

Pereira et al. (2015) applied 558, 475 and $438 \mathrm{~mm}$ of water in cactus pear for irrigation frequencies of 7, 14 and 28 days, respectively, and found that the different levels of water availability did not cause significant effects on plant height, plant width and total number of cladodes, which affect green biomass yield.

Studying irrigation depths in cactus pear, Queiroz et al. (2015) applied 976, 1048, 1096, 1152 and $1421 \mathrm{~mm}$ of water over 380 days of cultivation and concluded that the applied water depths did not promote significant changes in cactus pear morphology and yield; results that may be related to the fact that the irrigation depth is high for the crop.

From the volume of water applied, for each irrigation frequency, it was possible to estimate the potential of planted 
area in the hypothesis that the rural producer reduces the frequency of irrigation in cactus pear cultivation (Figure 4B).

When the irrigation frequency was reduced, there was a decrease in the volume of water applied, which allows the cactus pear producer to irrigate a larger area with the same amount of water, using low irrigation frequency, without significant losses in yield.

With the same volume of water applied at the irrigation frequency of 7 days $\left(3,147.5 \mathrm{~m}^{3} \mathrm{ha}^{-1}\right)$, it is possible to increase the planted area under the other irrigation frequencies. Thus, the volume of water applied at the irrigation frequency of 7 days is sufficient to cultivate $1.2,1.3,1.4$ and 1.5 ha at irrigation frequencies of 14, 21, 28 and 35 days, respectively (Figure $4 \mathrm{~B})$. These increments in planted area may result in higher yields for irrigation frequencies of 14,21, 28 and 35 days, with estimated green biomass productions of 66.3, 65.4, 63.9 and $60.1 \mathrm{t}$, respectively.

\section{Conclusions}

1. Different irrigation frequencies promote reduction in green biomass yield and increase in the economic water productivity when using of the cladode for propagative material.

2. Nitrogen fertilization increases plant growth, green biomass yield, water productivity and economic water productivity.

3. The highest economic return of cactus pear cv. 'Orelha de Elefante Mexicana' is obtained with the production of cladodes marketed for planting.

4. Reduction of irrigation frequency in cactus pear $\mathrm{cv}$. 'Orelha de Elefante Mexicana' promotes greater water saving, which allows the irrigated area to be increased.

\section{Literature Cited}

Araya, A.; Stroosnijder, L.; Girmay, G.; Keesstra, S. D. Crop coefficient, yield response to water stress and water productivity of teff (Eragrostis tef (Zucc.). Agricultural Water Management, v.98, p.775-783, 2011. http://dx.doi.org/10.1016/j.agwat.2010.12.001

Barros, J. L. de; Donato, S. L. R.; Gomes, V. M.; Donato, P. E. R.; Silva, J. A. da; Padilha Júnior, M. C. Palma forrageira 'gigante' cultivada com adubação orgânica. Revista Agrotecnologia, v.7, p.53-65, 2016. http://dx.doi.org/10.12971/2179-5959/agrotecnologia. v7n1p53-65

Cruz Neto, J. F. da Morais, J. E. F. de; Souza, C. A. A. de; Carvalho, H. F. de S.; Rodrigues, C. T. A.; Silva, T. G. F. da. Aplicabilidade de indicadores agrometeorológicos para análise do incremento de água por irrigação em sistemas de produção da palma forrageira, cv. Miúda. Journal of Environmental Analysis and Progress, v.2, p.98-106, 2017. http://dx.doi.org/10.24221/jeap.2.2.2017.1170.98106

Cunha, D. de N. F. V. da; Gomes, E. dos S.; Martuscello, J. A.; Amorim, P. L. de; Silva, R. C.; Ferreira, P. S. Morfometria e acúmulo de biomassa em palma forrageira sob doses de nitrogênio. Revista Brasileira de Saúde e Produção Animal, v.13, p.1156-1165, 2012. http://dx.doi.org/10.1590/S1519-99402012000400005
Donato, P. E. R., Pires, A. J. V., Donato, S. L. R., Bonomo, P., Silva, J. A.; Aquino, A. A. Morfometria e rendimento da palma forrageira 'Gigante' sob diferentes espaçamentos e doses de adubação orgânica. Revista Brasileira de Ciências Agrárias, v.9, p.151-158, 2014. http://dx.doi.org/10.5039/agraria.v9i1a3252

EMBRAPA - Empresa Brasileira de Pesquisa Agropecuária. Sistema brasileiro de classificação de solos. 4.ed. Rio de Janeiro: Embrapa Solos, 2014. 353p.

Ferreira, D. F. Sisvar: A guide for its bootstrap procedures in multiple comparisons. Ciência e Agrotecnologia, v.38, p.109-112, 2014. https://doi.org/10.1590/S1413-70542014000200001

Frizzone, J. A.; Freitas, P. S. L. de; Rezende, R.; Faria, M. A. de. Microirrigação: Gotejamento e microaspersão. 1.ed. Maringá, EDUEM. 2012. 356p.

Guan, D. H.; Zhang, Y. S.; Mahdi, M. A.; Wang, Q. Y.; Zhang, M. C.; $\mathrm{Li}, \mathrm{Z}$. H. Tillage practices effect on root distribution and water use efficiency of winter wheat under rain-fed condition in the North China Plain. Soil and Tillage Research, v.146, p.286-295, 2015. https://doi.org/10.1016/j.still.2014.09.016

Lima, A. S. de; Dantas Neto, J.; Matos, R. M. de; Silva, P. F. da; Saboya, L. M. F.; Lima, V. L. A. de. Determinação da capacidade de campo in situ por diferentes métodos em Neossolo do semiárido. Revista Brasileira de Agricultura Irrigada v.11, p. 1598-1605, 2017. DOI: 10.7127/rbai.v11n400624

Lima, G. F. da C.; Rego, M. M. T.; Dantas, F. D. G.; Lôbo, R. N. B.; Silva, J. G. M. da; Aguiar, E. M. de. Morphological characteristics and forage productivity of irrigated cactus pear under different cutting intensities. Revista Caatinga, v.29, p.481-488, 2016. http:// dx.doi.org/10.1590/1983-21252016v29n226rc

Nascimento, J. P. do; Souto, J. S.; Santos, E. S. dos; Damasceno, M. M.; Ramos, J. P. de F.; Sales, A. T.; Leite, M. L. de M. V. Caracterização morfométrica de Opuntia fícus indica sob diferentes arranjos populacionais e fertilização fosfatada. Tecnologia \& Ciências Agropecuárias, v.5, p.21-26, 2011.

Pereira, P. de C.; Silva, T. G. F. da; Zolnier, S.; Morais, J. E. F. de Santos, D. C. dos. Morfogênese da palma forrageira irrigada por gotejamento. Revista Caatinga, v.28, p.184-195, 2015. http:// dx.doi.org/10.1590/1983-21252015v28n321rc

Pinheiro, K. M.; Silva, T. G. F. da; Carvalho, H. F. de S.; Santos, J. E. O.; Morais, J. E. F. de; Zolnier, S.; Santos, D. C.dos. Correlações do índice de área do cladódio com características morfogênicas e produtivas da palma forrageira. Revista Pesquisa Agropecuária Brasileira, v.49, p.939-947, 2014. http://dx.doi.org/10.1590/S0100204X2014001200004

Queiroz, M. G. de; Silva, T. G. F. da; Zolnier, S.; Silva, S. M. S. e; Lima, L. R.; Alves, J. de O. Características morfofisiológicas e produtividade da palma forrageira em diferentes lâminas de irrigação. Revista Brasileira de Engenharia Agrícola e Ambiental, v.19, p.931-938, 2015. http://dx.doi.org/10.1590/1807-1929/ agriambi.v19n10p931-938

Rocha, R. S.; Voltolini, T. V.; Gava, C. A. T. Características produtivas e estruturais de genótipos de palma forrageira irrigada em diferentes intervalos de corte. Archivos de Zootecnia, v.66, p.365373, 2017. https://doi.org/10.21071/az.v66i255.2512

Santos, D. C. dos; Farias, I.; Lira, M. de A.; Santos, M. V. F. dos; Arruda, G. P. de; Coelho, R. S. B.; Dias, F. M.; Melo, J. N. de. Manejo e utilização da palma forrageira (Opuntia e Nopalea) em Pernambuco. Recife: IPA, 2006. 48p. Documentos, 30 
Silva, J. A.; Bonomo, P.; Donato, S. L. R.; Pires, A. J. V.; Rosa, R. C. C.; Donato, P. E. R. Composição mineral em cladódios de palma forrageira sob diferentes espaçamentos e adubações química. Revista Brasileira de Ciências Agrárias, v.7, p.866-875, 2012. https://doi.org/10.5039/agraria.v7isa2134

Silva, N. G. de M. e; Lira, M. de A.; Santos, M. V. F. dos; Dubeux Júnior, J. C. B.; Mello, A. C. L. de; Silva, M. da C. Relação entre características morfológicas e produtivas de clones de palma-forrageira. Revista Brasileira de Zootecnia, v.39, p.2389-2397, 2010. http://dx.doi.org/10.1590/S151635982010001100011

Silva, P. F. da; Dantas Neto, J.; Lima, V. L. A. de; Santos, D. B. dos; Ribeiro, P. H. P. Evaluation of emitters self compensate irrigating with saline water: Part II: Process capability index1. Engenharia Agrícola. v.36, p.540-550, 2016a. http://dx.doi.org/10.1590/18094430-eng.agric.v36n6p1086-1095/2016
Silva, P. F. da; Matos, R. M. de; Borges, V. E.; Dantas Neto, J.; Farias, M. S. S. de. Morphology and biomass yield of forage cactus under mineral fertilization in organic soil. African Journal of Agricultural Research, v.11, p.3497-3505, 2016b. http://dx.doi.org/10.5897/AJAR2016.11420 Silva, T. G. F. da; Araújo Primo, J. T.; Morais, J. E. F. de; Diniz, W. J. da S.; Souza, C. A. A. de; Silva, M. da C. Crescimento e produtividade de clones de palma forrageira no semiárido e relações com variáveis meteorológicas. Revista Caatinga, v.28, p.10-18, 2015.

Silva, T. G. F. da; Primo, J. T. A.; Silva, S. M. S. e; Moura, M. S. B. de; Santos, D. C. dos; Silva, M. da C.; Araújo, J. E. M. Indicadores de eficiência do uso da água e de nutrientes de clones de palma forrageira em condições de sequeiro no Semiárido brasileiro. Bragantia, v.73, p.184-191, 2014. http://dx.doi.org/10.1590/ brag.2014.017

Taiz, L.; Zeiger, E. Fisiologia vegetal. 5.ed. Porto Alegre:Artemed, 2013. 954p. 